\title{
Ramsay Hunt syndrome: characteristics and patient self-assessed long-term facial palsy outcome
}

\author{
Mervi Kanerva $^{1}$ (D) Sanna Jones ${ }^{2} \cdot$ Anne Pitkaranta $^{1}$
}

Received: 9 December 2019 / Accepted: 20 January 2020 / Published online: 25 January 2020

(c) The Author(s) 2020

\begin{abstract}
Purpose To explore the characteristics, medical treatments, and long-term facial palsy outcome in Ramsay Hunt syndrome. Methods Patient questionnaire including self-assessment of long-term facial palsy outcome and retrospective chart review. Initial facial palsy grade was compared to self-assessed or patient record stated palsy outcome. Occurrence of different characteristics (blisters, hearing loss, vertigo, etc.) of the syndrome were assessed.

Results Altogether 120 patients were included of which 81 answered the questionnaire. All but one patient had received virus medication (aciclovir, valaciclovir), and half received simultaneous corticosteroids. If the medication was started within 72 $\mathrm{h}$ of Ramsay Hunt diagnosis, facial palsy recovered totally or with only slight sequelae in over $80 \%$ of the patients. Only a minority of the patients experienced varicella blisters simultaneously with facial palsy, blisters more often preceded or followed the palsy. Approximately $20 \%$ of the patients had their blisters in hidden places in the ear canal or mouth.

Conclusions The long-term outcome of facial palsy in medically treated Ramsay Hunt syndrome was approaching the outcome of Bell's palsy. It is crucial to ask and inform the patient about the blisters and look for them since, more often than not, the blisters precede or follow the palsy and can be in areas not easily seen.
\end{abstract}

Keywords Herpes zoster oticus · Facial paralysis · Varicella-Zoster virus · House-Brackmann · Sunnybrook · Facial grading $\cdot$ Facial sequelae

\section{Introduction}

Ramsay Hunt syndrome (RHS) consists of peripheral facial palsy (FP) of the VII cranial nerve (CN) and herpes blisters in the head and neck area. All nerves that communicate with the facial nerve can be involved e.g. CNs V, VIII, IX, and $\mathrm{X}$ and cervical nerves $\mathrm{C} 2, \mathrm{C} 3$, and $\mathrm{C} 4$ [1]. Hearing loss, tinnitus, and vertigo frequently accompany facial palsy [2]. RHS is caused by reactivation of latent varicella-zoster virus (VZV) [2, 3]. Even though cranial polyneuropathy including many additional CNs (e.g. III, XI, XII) was not included in the original definition of RHS, investigators have reported such patients as rare cases of RHS [1, 4, 5].

Mervi Kanerva

mervi.kanerva@gmail.com

1 Department of Otorhinolaryngology-Head and Neck Surgery, Helsinki University Hospital and University of Helsinki, PO Box 263, 00029 HUS Helsinki, Finland

2 Terveystalo Occupational Healthcare Services, Leppavaara and Espoontori, Espoo, Finland
There are no prospective studies on RHS, specifically. Peitersen [6] studied idiopathic peripheral FP and gathered all cases throughout 25 years in Copenhagen, Denmark. In this group of $2570 \mathrm{FP}$ patients, there were 116 cases of RHS. The annual incidence was 2.2/100,000; which was approximately $4.5 \%$ of all FPs. Estimates of incidence based on mostly retrospective studies of individual centers have ranged $4-12 \%$ of all FPs and around 5/100,000/year [7, 8].

The clinical picture of RHS includes three possibilities regarding the timing of the relationship between FP and blisters. If the blisters occur before or simultaneously with the palsy, RHS diagnosis is usually easy. Sometimes the blisters are not very noticeable and can be overlooked by the inspector, if RHS is not considered in patients experiencing FP. Similarly, in cases where FP presents first, and blisters later, clinical RHS diagnosis is impossible at the time of palsy onset.

Recognizing RHS has become more important with the widely accepted practice of treating these patients with antiviral agents along with corticosteroids even though consensus is missing [9-11]. Comparing recovery results from 
the time before and after the use of antiviral treatments and knowing that shingles patients benefit from medical therapy [12,13], recommendations have been published for the combined use of antivirals and corticosteroids $[11,14]$. No prospective medical studies likely will exist that compare different medical treatments to no medications at all in RHS, but we can study the patients and how they have recovered in order to draw some suggestive conclusions about the treatment results.

The aim of this study was to investigate the characteristics and treatment of RHS and to determine the long-term outcome of FP in RHS patients using patient charts retrospectively and one-time patient questionnaire.

\section{Materials and methods}

A computer search of patient records for RHS from 1/1996 to $1 / 2013$ was performed in Helsinki University Central Hospital, Department of Otorhinolaryngology-Head and Neck Surgery. Patients with peripheral FP and a history or recognition of blisters in the head and neck area within 1 month prior, concomitantly with palsy onset, or 1 month following the palsy onset, were included in the study. Some patients had to be removed from the study, since the history of the blisters was indefinite, and one patient because of a malignancy behind the symptoms. The time, when RHS diagnosis was possible to make, was considered RHS onset.

Besides using the patient records for the data collection, the patients were sent a questionnaire asking about their RHS symptoms and how they had recovered, and were asked to grade their FP outcome.

FP grading methods in patient records varied and both House-Brackmann (HB) [15] and Sunnybrook (SB) [16] grading scales had been used. For study purposes, SB grades were converted to HB grades according to Conversion Table [17].

We used SPSS (Armonk, NY: IBM Corp.) versions 22-24 for statistical analyses. We used descriptive statistics to summarize the frequencies, proportions, medians, and ranges. Fischer's Exact Test was used to calculate the significances.

\section{Results}

\section{Patients}

Inclusion criteria were met by 120 patients: 71 women and 49 men. At the time of the study, 8 of the 120 patients had died and 4 could not be reached. The remaining 108 patients were sent a questionnaire about their RHS. Of these, 81 answered the questionnaire (52 women, 29 men). The caregiver of an additional three patients informed that due to the patients' illnesses, they were no longer capable of answering the questionnaire.

Of the 120 patients, 59 experienced FP on the right, and 61 on the left. Of the 81 patients answering the questionnaire, 40 experienced FP on the right, and 41 on the left.

Age at time of RHS onset for the 120 patients varied from 6.9 to 94.7 years. The median age for women was 56.4 years (range 12.2-94.7), for men 48.8 years (range 6.9-84.3). Patients answering the questionnaire were aged 6.9-88.2 years. The median age was 52.3 years (range 2.2-88.2) for women, and 49.1 years (range 6.9-84.3) for men. Five of these patients were 16 years or younger at RHS onset.

The median follow-up time for the 81 patients answering the questionnaire was 6.6 years (range 1-17.1). For those failing to answer the questionnaire, the data were solely collected from the patient records: FP of 26 patients had recovered to total or near total in a median of 3.4 months (range 0.6-12.1) and no additional follow-up times were scheduled. For the remaining 13 (of the 120 patients), 4 were lost in follow-up after their initial visit and 9 patients had a followup median of 7.2 months (range 1.2-12.1).

\section{Medical treatment}

At RHS onset, all but one of the 120 patients were prescribed either intravenous or oral antiviral medication (aciclovir or valaciclovir) (Table 1). Of the prescription-receiving patients, 57 (48\%) were also prescribed concomitant corticosteroids (prednisolon or methylprednisolon). One patient receiving both aciclovir and prednisolone prescription admitted not taking either of the medicines and was placed in the "no-medication" group for the outcome results in this study.

Of the 120 patients, 104 (87\%) received their medication within $48 \mathrm{~h}$, an additional 3 (2\%) patients within $72 \mathrm{~h}, 12$ (10\%) patients over $72 \mathrm{~h}$ from the onset of RHS (one not consuming the medication), and $1(1 \%)$ received no medication at all (Table 1).

\section{Blisters}

From patient charts, the location of VZV blisters could be identified for 119 patients. The most frequent area to be affected was the ear. Outer ear, with or without ear canal involvement, was the sole place for blisters in 62 patients $(52 \%)$. In addition, in 7 patients $(6 \%)$ only the ear canal or the ear drum were infected, with no outside visible blisters. Taken together, the ear by itself counted for 58\% of the cases. Ear was additionally involved as follows: ear and mouth 4 patients (3\%); ear, mouth, and additional area 3 patients (2\%); and ear and additional area (apart from mouth) 15 patients (13\%). Thus, the ear was one of the areas affected in 91 patients (76\%). Mouth cavity 
Table 1 Long-term outcome of Ramsay Hunt syndrome facial palsy combined from patient records and patient's self-assessment questionnaire and compared to initial facial palsy grade

\begin{tabular}{|c|c|c|c|c|c|}
\hline \multirow[t]{2}{*}{ Medication at Ramsay Hunt syndrome onset } & \multirow[t]{2}{*}{$\begin{array}{l}\text { Number } \\
\text { of patients } \\
\text { (total }=120)\end{array}$} & \multicolumn{4}{|c|}{$\begin{array}{l}\text { Medication onset time from Ramsay Hunt diagnose/ } \\
\text { patient number } \\
\text { Initial HB grade }{ }^{\mathrm{a}} \rightarrow \text { outcome }^{\mathrm{b}} / \text { patient number }\end{array}$} \\
\hline & & $\leq 24 \mathrm{~h}$ & $\leq 48 \mathrm{~h}$ & $\leq 72 \mathrm{~h}$ & $>72 \mathrm{~h}$ \\
\hline Valaciclovir orally $1 \mathrm{~g} \times 3 \times 7$ & 18 & $\begin{array}{l}15 \\
\text { HB II } \rightarrow 1 / 3 \\
\text { HB III } \rightarrow 1 / 1 \\
\text { HB VI } \rightarrow 2 / 1 \\
\text { HB } ? \rightarrow 1 / 3 \\
\text { HB } ? \rightarrow 2 / 6 \\
\text { HB } ? \rightarrow 3 / 1\end{array}$ & & $\begin{array}{l}1 \\
\mathrm{HB} ? \rightarrow 1 / 1\end{array}$ & $\begin{array}{l}2 \\
\mathrm{HB} \text { II } \rightarrow 1 / 1 \\
\mathrm{HB} ? \rightarrow 2 / 1\end{array}$ \\
\hline Valaciclovir orally, dosing unclear & 3 & $\begin{array}{l}3 \\
\mathrm{HB} \mathrm{V} \rightarrow 1 / 1 \\
\mathrm{HB} \mathrm{V} \rightarrow 2 / 1 \\
\mathrm{HB} ? \rightarrow 1 / 1\end{array}$ & & & \\
\hline Valaciclovir orally $1 \mathrm{~g} \times 3 \times 7+$ corticosteroid $^{\mathrm{c}}$ & 41 & $\begin{array}{l}37 \\
\text { HB II } \rightarrow 1 / 1 \\
\text { HB III } \rightarrow 1 / 2 \\
\text { HB III } \rightarrow 4 / 1 \\
\text { HB IV } \rightarrow 1 / 4 \\
\text { HB IV } \rightarrow 2 / 2 \\
\text { HB IV } \rightarrow ? / 1 \\
\text { HB V } \rightarrow 1 / 1 \\
\text { HB V } \rightarrow 2 / 1 \\
\text { HB V } \rightarrow 3 / 1 \\
\text { HB VI } \rightarrow 1 / 3 \\
\text { HB VI } \rightarrow 3 / 3 \\
\text { HB VI } \rightarrow ? / 1 \\
\text { HB } ? \rightarrow 1 / 7 \\
\text { HB } ? \rightarrow 2 / 7 \\
\text { HB } ? \rightarrow 3 / 2\end{array}$ & $\begin{array}{l}2 \\
\mathrm{HB} \mathrm{II} \rightarrow 1 / 1 \\
\mathrm{HB} \mathrm{V} \rightarrow 1 / 1\end{array}$ & $\begin{array}{l}1 \\
\mathrm{HB} \mathrm{V} \rightarrow 1 / 1\end{array}$ & $\begin{array}{l}1 \\
\mathrm{HB} \mathrm{V} \rightarrow 3 / 1\end{array}$ \\
\hline Aciclovir orally $800 \mathrm{mg} \times 5 \times 7$ & 9 & $\begin{array}{l}7 \\
\mathrm{HB} \mathrm{III} \rightarrow 2 / 1 \\
\mathrm{HB} \text { III } \rightarrow ? / 1 \\
\mathrm{HB} \mathrm{IV} \rightarrow 2 / 1 \\
\mathrm{HB} \mathrm{V} \rightarrow 1 / 1 \\
\mathrm{HB} ? \rightarrow 1 / 3\end{array}$ & & & $\begin{array}{l}2 \\
\mathrm{HB} \text { VI } \rightarrow 2 / 1 \\
\mathrm{HB} ? \rightarrow 1 / 1\end{array}$ \\
\hline Aciclovir orally $800 \mathrm{mg} \times 5 \times 7+$ corticosteroid $^{\mathrm{c}}$ & 3 & $\begin{array}{l}3 \\
\mathrm{HB} \mathrm{II} \rightarrow 2 / 1 \\
\mathrm{HB} \mathrm{VI} \rightarrow 3 / 1 \\
\mathrm{HB} ? \rightarrow 1 / 1\end{array}$ & & & \\
\hline Aciclovir orally, dosing under $800 \mathrm{mg} \times 5 \times 7$ or unclear & 9 & $\begin{array}{l}7 \\
\text { HB IV } \rightarrow 1 / 1 \\
\text { HB } ? \rightarrow 1 / 4 \\
\text { HB } ? \rightarrow 2 / 2\end{array}$ & $\begin{array}{l}1 \\
\mathrm{HB} ? \rightarrow 3 / 1\end{array}$ & & $\begin{array}{l}1 \\
\mathrm{HB}\end{array} \rightarrow ? / 1$ \\
\hline Aciclovir intra venous under $10 \mathrm{mg} / \mathrm{kg} / \mathrm{day} \times 3$ or unclear & 3 & $\begin{array}{l}3 \\
\text { HB II } \rightarrow 1 / 1 \\
\text { HB IV } \rightarrow 1 / 1 \\
\text { HB } ? \rightarrow 4 / 1\end{array}$ & & & \\
\hline $\begin{array}{l}\text { Aciclovir orally under } 800 \mathrm{mg} \times 5 \times 7 \text { or intra venous under } 10 \\
\mathrm{mg} / \mathrm{kg} / \text { day } \times 3+\text { corticosteroid }^{\mathrm{c}}\end{array}$ & 3 & $\begin{array}{l}3 \\
\mathrm{HB} \mathrm{II} \rightarrow 1 / 1 \\
\mathrm{HB} \mathrm{V} \rightarrow 2 / 1 \\
\mathrm{HB} ? \rightarrow 1 / 1\end{array}$ & & & \\
\hline
\end{tabular}


Table 1 (continued)

\begin{tabular}{|c|c|c|c|c|c|}
\hline \multirow[t]{2}{*}{ Medication at Ramsay Hunt syndrome onset } & \multirow[t]{2}{*}{$\begin{array}{l}\text { Number } \\
\text { of patients } \\
\text { (total }=120)\end{array}$} & \multicolumn{4}{|c|}{$\begin{array}{l}\text { Medication onset time from Ramsay Hunt diagnose/ } \\
\text { patient number } \\
\text { Initial HB grade }{ }^{\mathrm{a}} \rightarrow \text { outcome }^{\mathrm{b}} / \text { patient number }\end{array}$} \\
\hline & & $\leq 24 \mathrm{~h}$ & $\leq 48 \mathrm{~h}$ & $\leq 72 \mathrm{~h}$ & $>72 \mathrm{~h}$ \\
\hline Aciclovir intra venous minimum $10 \mathrm{mg} / \mathrm{kg} / \mathrm{day} \times 3$ & 19 & $\begin{array}{l}14 \\
\text { HB II } \rightarrow 1 / 1 \\
\text { HB III } \rightarrow 1 / 1 \\
\text { HB V } \rightarrow 1 / 1 \\
\text { HB V } \rightarrow 2 / 1 \\
\text { HB V } \rightarrow 3 / 1 \\
\text { HB VI } \rightarrow 2 / 1 \\
\text { HB VI } \rightarrow 3 / 1 \\
\text { HB ? } \rightarrow 1 / 3 \\
\text { HB ? } \rightarrow 2 / 2 \\
\text { HB ? } \rightarrow 4 / 1 \\
\text { HB } ? \rightarrow ? / 1\end{array}$ & $\begin{array}{l}2 \\
\mathrm{HB} ? \rightarrow 1 / 1 \\
\mathrm{HB} ? \rightarrow 1 / 1\end{array}$ & & $\begin{array}{l}3 \\
\text { HB II } \rightarrow 3 / 1 \\
\text { HB II } \rightarrow 1 / 1 \\
\text { HB VI } \rightarrow 4 / 1\end{array}$ \\
\hline $\begin{array}{l}\text { Aciclovir intra venous minimum } 10 \mathrm{mg} / \mathrm{kg} / \mathrm{day} \times 3+\text { corticoster- } \\
\text { oid }^{\mathrm{c}}\end{array}$ & 10 & $\begin{array}{l}7 \\
\text { HB II } \rightarrow 2 / 1 \\
\text { HB IV } \rightarrow 1 / 1 \\
\text { HB V } \rightarrow 1 / 2 \\
\text { HB V } \rightarrow 3 / 1 \\
\text { HB VI } \rightarrow 4 / 1 \\
\text { HB } ? \rightarrow 2 / 1\end{array}$ & & $\begin{array}{l}1 \\
\mathrm{HB} \mathrm{V} \rightarrow 2 / 1\end{array}$ & $\begin{array}{l}2 \\
\mathrm{HB} ? \rightarrow 3 / 1 \\
\mathrm{HB} ? \rightarrow 1 / 1\end{array}$ \\
\hline No medication & 2 & & & & $\begin{array}{l}2 \\
\mathrm{HB} ? \rightarrow 2 / 1 \\
\mathrm{HB} ? \rightarrow 3 / 1\end{array}$ \\
\hline
\end{tabular}

Patients are grouped by the medication type and medication start time at syndrome onset

${ }^{a}$ Initial facial palsy grade was available from 62 patient records, graded by House-Brackmann scale (HB) or Sunnybrook scale, latter converted here to $\mathrm{HB}$ grades

${ }^{\mathrm{b}}$ Facial palsy outcome: 1 -totally recovered; 2 -slight sequelae; 3-obvious sequelae; 4 -severe sequelae

${ }^{\mathrm{c}}$ Corticosteroid usually Prednisolon $60 \mathrm{mg} /$ day with tapering dosing $10 \mathrm{mg} / \mathrm{day}$ after 5 days for 10 days or Medrol $32 \mathrm{mg}$ or $64 \mathrm{mg} / \mathrm{day}$ for 7-10 days

was solely affected in 14 patients (12\%) and in addition to prementioned times with ear, in 2 patients (2\%) mouth was affected with other area facial blisters. Face, neck, and shoulders without ear or mouth involvement were affected in 12 patients (10\%).

VZV blisters preceded FP in 58 patients (48\%), were concomitant in 19 patients (16\%), and followed the palsy onset in 43 patients (36\%).

From 58 patients' charts, the time difference between the blisters appearing before FP could be assessed: 1-2 days prior in 15 cases (26\%), 3-7 days prior in 25 cases (43\%), 8-14 days prior in 13 cases (22\%), and over 14 $(\leq 30)$ days prior in 5 cases $(9 \%)$.

The information about the time difference between FP preceeding blisters could be obtained from 43 patient charts: 1-2 days prior in 20 cases (46\%), 3-7 days prior in 17 cases $(40 \%), 8-14$ days prior in 3 cases $(7 \%)$, and over $14(\leq 30)$ days prior in 3 cases $(7 \%)$.

\section{Hearing loss}

An audiogram had been taken from 103 patients; In 54 (52\%) there was an acute hearing loss linked to the RHS. In 8 of these cases, there was a mention that the hearing loss was mild (the audiogram itself was not obtainable). No comprehensive audiometry testing could be found at the end of the follow-up time for all the study patients. Of those 81 patients answering the questionnaire, 18 (22\%) answered that they were left with a hearing loss after the illness, 7 (9\%) were not sure, and $56(69 \%)$ answered they had no hearing loss because of RHS.

\section{Other symptoms}

From the patient charts $(n=120)$, mentions of accompaning symptoms could be gathered from 110 patients: symptoms around the affected ear 86 (78\%) (ache, fullness e.g.), ache 
in some other area 24 (22\%), vertigo/dizziness 34 (31\%), and additional mentions of nausea, vomiting, tinnitus, and hyperacusia.

Of the 81 patients answering the questionnaire, $73 \mathrm{com}$ mented on the symptoms from the acute period of RHS onset: ache around the affected ear $56(77 \%)$, vertigo/dizziness $37(51 \%)$, hearing loss $33(45 \%)$, and dryness of the affected eye $31(42 \%)$. Other frequently mentioned symptoms were nausea, tinnitus, dysgeusia, vomiting, and dryness of the mouth. At the questionnaire's open area for extra reporting "other areas of pain" was mentioned frequently. For the questions about persistent symptoms after minimum of 1 year recovery time 26 (32\%) mentioned having persistent vertigo or dizziness because of the RHS, $5(6 \%)$ patients were not sure, and 50 (62\%) experienced no balance disturbances. Tinnitus was experienced by $24(30 \%)$ patients, dry mouth by 21 (26\%), facial numbness by $21(26 \%)$, and excessive tearing by $23(28 \%)$.

\section{Immunocompromised patients}

Altogether $12(10 \%)$ of the 120 patients either had an illness or took medication that made them immunocompromised and could have predisposed them to RHS.

\section{FP or RHS history}

Amongst those 81 patients answering the questionnaire, 7 (9\%) had a relative who had experienced FP. No one had a relative with RHS history. There was one patient with previous FP from which she was totally cured. Two patients had suspected a new FP after the RHS, but there were no patient charts for review of the incidence and the symptoms had disappeared in a day or two. There were no patients with recurrent RHS.

\section{FP recovery from patient questionnaire}

Table 2 shows the FP outcome of patient self-assessment from the questionnaire. There was no statistical difference in outcome, whether the patient received "gold standard" shingles virus medication or whether the amount of the medication was unclear (Tables 2, 3, 4). Similarly, there was no statistical difference whether the medication included corticosteroids or not. The outcome stayed the same as long as the medication was started within $72 \mathrm{~h}$ of RHS onset with $64(84 \%)$ of the patients totally cured or left only with slight sequelae (Tables 2, 3, 4). In total paralysis (HB VI) the FP outcome to total or good recovery with medication within $72 \mathrm{~h}$ was achieved by 3 of the 7 patients $(43 \%$ ) (Tables 3,4 ). Already in $\mathrm{HB}$ grade $\mathrm{V}$, the recovery to that same grade was achieved by 5 of 7 and 8 of 10 patients (70-80\%) (Tables 3 , 4).
The number of patients receiving their medication later than $72 \mathrm{~h}$ or taking no medication at all was low, only $6(7 \%$ of 81), but regardless of the initial FP grade, none recovered totally and only 2 (33\% of 6 ) recovered to having only slight sequelae (Table 2 ).

\section{FP recovery from patient records and questionnaire combined}

Combining questionnaire results and patient chart results, FP outcome could be estimated to $116(97 \%)$ of the 120 patients (Tables 1, 5). Of all the patients, $107(89 \%)$ received virus medication ( \pm corticosteroids) within $72 \mathrm{~h}$ and for 103 of them $(96 \%)$ a long-term FP outcome could be determined; $87(84 \%)$ were cured totally or were left only with slight sequelae (Tables 1,5$)$. Two patients $(2 \%)$ took no medications and for $11(9 \%)$ patients the medication was started over $72 \mathrm{~h}$ from the RHS onset. FP outcome was known for 12 of these 13 patients: 7 (58\%) were cured totally or were left only with slight sequelae; and $5(42 \%)$ were left with obvious or severe sequelae. The patient number in each initial HB grade was as follows: HB II, 3; HB V, 1; HB VI, 2; and HB?, 7. A Fisher's two-sided Exact Test failed to reach significance $(P=0.060)$ when comparing the results of these two groups: those receiving any medication within $72 \mathrm{~h}$ and those receiving medication over $72 \mathrm{~h}$ from RHS onset or none at all. Tables 5, 6, 7, and 8 show that there was no significant difference on FP long-term outcome between the different types of medications. Initial total paralysis seamed to lead to worse outcome results in all medication groups (Tables 1, 5, 6, 7, 8).

\section{Discussion}

\section{FP outcome}

In our study, good recovery (total recovery or recovery with only slight sequelae; comparable to HB grades I and II [17]) was obtained by over $80 \%$ of the patients receiving antiviral therapy within $72 \mathrm{~h}$ from RHS onset. These results are in concordance with results from other studies where medical therapy (antivirals \pm corticosteroids) has been used. Even though in our study almost all patients received antiviral therapy, only half received simultaneous corticosteroid treatment. A good recovery rate has been reported by Uri et al. [18] for 26/31 (83\%) patients (HB I \& II); Murakami et al. [14] for $65 / 80(81 \%)$ (HB I \& II); Shim et al. [1] for 223/328 (68\%) (HB I \& II); Kiniski [19] for 85/91 (93\%); Zainine et al. [20] for 10/15 (67\%) (HB I \& II); and Coulson et al. [21] for 60/101 (59\%) (HB I \& II). Before the use of virus or combination medication, worse recovery results were reported. In Peitersen's study [6], "fair recovery" with 
Table 2 Long-term outcome of Ramsay Hunt syndrome facial palsy by patient's self-assessment questionnaire compared to the initial facial palsy grade

\begin{tabular}{|c|c|c|c|c|c|}
\hline \multirow[t]{2}{*}{ Medication at Ramsay Hunt syndrome onset } & \multirow[t]{2}{*}{$\begin{array}{l}\text { Number } \\
\text { of patients } \\
\text { (total }=81)\end{array}$} & \multicolumn{4}{|c|}{$\begin{array}{l}\text { Medication onset time from Ramsay Hunt diagnose/patient } \\
\text { number } \\
\text { Initial HB grade }{ }^{\mathrm{a}} \rightarrow \text { patient self-graded facial palsy } \\
\text { outcome }^{\mathrm{b}} \text { patient number }\end{array}$} \\
\hline & & $\leq 24 \mathrm{~h}$ & $\leq 48 \mathrm{~h}$ & $\leq 72 \mathrm{~h}$ & $>72 \mathrm{~h}$ \\
\hline Valaciclovir orally $1 \mathrm{~g} \times 3 \times 7$ & 10 & $\begin{array}{l}9 \\
\text { HB II } \rightarrow 1 / 1 \\
\text { HB III } \rightarrow 1 / 1 \\
\text { HB VI } \rightarrow 2 / 1 \\
\text { HB } ? \rightarrow 1 / 2 \\
\text { HB ? } \rightarrow 2 / 4\end{array}$ & & $\begin{array}{l}1 \\
\mathrm{HB} ? \rightarrow 1 / 1\end{array}$ & \\
\hline Valaciclovir orally, dosing unclear & 3 & $\begin{array}{l}3 \\
\mathrm{HB} \mathrm{V} \rightarrow 1 / 1 \\
\mathrm{HB} \mathrm{V} \rightarrow 2 / 1 \\
\mathrm{HB} ? \rightarrow 1 / 1\end{array}$ & & & \\
\hline Valaciclovir orally $1 \mathrm{~g} \times 3 \times 7+$ corticosteroid $^{\mathrm{c}}$ & 32 & $\begin{array}{l}28 \\
\text { HB II } \rightarrow 1 / 1 \\
\text { HB III } \rightarrow 1 / 2 \\
\text { HB III } \rightarrow 4 / 1 \\
\text { HB IV } \rightarrow 1 / 2 \\
\text { HB IV } \rightarrow 2 / 2 \\
\text { HB V } \rightarrow 2 / 1 \\
\text { HB V } \rightarrow 3 / 1 \\
\text { HB VI } \rightarrow 1 / 1 \\
\text { HB VI } \rightarrow 3 / 3 \\
\text { HB ? } \rightarrow 1 / 7 \\
\text { HB } ? \rightarrow 2 / 5 \\
\text { HB } ? \rightarrow 3 / 2\end{array}$ & $\begin{array}{l}2 \\
\mathrm{HB} \mathrm{II} \rightarrow 1 / 1 \\
\mathrm{HB} \mathrm{V} \rightarrow 1 / 1\end{array}$ & $\begin{array}{l}1 \\
\mathrm{HB} \mathrm{V} \rightarrow 1 / 1\end{array}$ & $\begin{array}{l}1 \\
\mathrm{HB} \mathrm{V} \rightarrow 3 / 1\end{array}$ \\
\hline Aciclovir orally $800 \mathrm{mg} \times 5 \times 7$ & 6 & $\begin{array}{l}5 \\
\mathrm{HB} \text { III } \rightarrow 2 / 1 \\
\mathrm{HB} \text { IV } \rightarrow 2 / 1 \\
\mathrm{HB} ? \rightarrow 1 / 3\end{array}$ & & & $\begin{array}{l}1 \\
\mathrm{HB} \text { VI } \rightarrow 2 / 1\end{array}$ \\
\hline Aciclovir orally $800 \mathrm{mg} \times 5 \times 7+$ corticosteroid $^{\mathrm{c}}$ & 2 & $\begin{array}{l}2 \\
\mathrm{HB} \text { II } \rightarrow 2 / 1 \\
\mathrm{HB} ? \rightarrow 1 / 1\end{array}$ & & & \\
\hline Aciclovir orally, dosing under $800 \mathrm{mg} \times 5 \times 7$ or unclear & 5 & $\begin{array}{l}4 \\
\mathrm{HB} \text { IV } \rightarrow 1 / 1 \\
\mathrm{HB} ? \rightarrow 1 / 2 \\
\mathrm{HB} ? \rightarrow 2 / 1\end{array}$ & $\begin{array}{l}1 \\
\mathrm{HB} ? \rightarrow 3 / 1\end{array}$ & & \\
\hline Aciclovir intra venous under $10 \mathrm{mg} / \mathrm{kg} / \mathrm{day} \times 3$ or unclear & 2 & $\begin{array}{l}2 \\
\mathrm{HB} \text { II } \rightarrow 1 / 1 \\
\mathrm{HB} ? \rightarrow 4 / 1\end{array}$ & & & \\
\hline $\begin{array}{l}\text { Aciclovir orally under } 800 \mathrm{mg} \times 5 \times 7 \text { or intra venous under } 10 \\
\mathrm{mg} / \mathrm{kg} / \mathrm{day} \times 3+\text { corticosteroid }^{\mathrm{c}}\end{array}$ & 3 & $\begin{array}{l}3 \\
\text { HB V } \rightarrow 2 / 1 \\
\text { HB II } \rightarrow 1 / 1 \\
\text { HB } ? \rightarrow 1 / 1\end{array}$ & & & \\
\hline Aciclovir intra venous minimum $10 \mathrm{mg} / \mathrm{kg} / \mathrm{day} \times 3$ & 12 & $\begin{array}{l}10 \\
\mathrm{HB} \text { II } \rightarrow 1 / 1 \\
\mathrm{HB} \text { III } \rightarrow 1 / 1 \\
\mathrm{HB} \text { V } \rightarrow 2 / 1 \\
\mathrm{HB} \text { V } \rightarrow 3 / 1 \\
\mathrm{HB} \text { VI } \rightarrow 2 / 1 \\
\mathrm{HB} ? \rightarrow 1 / 2 \\
\mathrm{HB} ? \rightarrow 2 / 2 \\
\mathrm{HB} ? \rightarrow 4 / 1\end{array}$ & $\begin{array}{l}1 \\
\mathrm{HB} ? \rightarrow 1 / 1\end{array}$ & & $\begin{array}{l}1 \\
\mathrm{HB} I I-3\end{array}$ \\
\hline Aciclovir intra venous minimum $10 \mathrm{mg} / \mathrm{kg} / \mathrm{d} \times 3+$ corticosteroid $^{\mathrm{c}}$ & 4 & $\begin{array}{l}3 \\
\mathrm{HB} \mathrm{II} \rightarrow 2 / 1 \\
\mathrm{HB} \mathrm{V} \rightarrow 1 / 1 \\
\mathrm{HB} \mathrm{VI} \rightarrow 3 / 1\end{array}$ & & & $\begin{array}{l}1 \\
\mathrm{HB} ? \rightarrow 3 / 1\end{array}$ \\
\hline
\end{tabular}


Table 2 (continued)

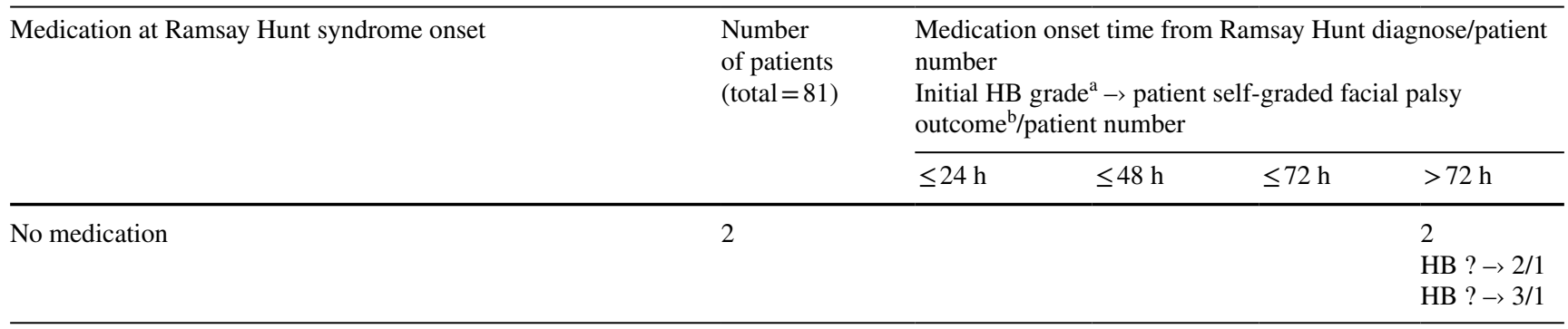

${ }^{\mathrm{a}}$ Initial facial palsy grade was available from 40 patient records, graded by House-Brackmann scale (HB) or Sunnybrook scale, latter converted here to HB grades

${ }^{\mathrm{b}}$ Facial palsy outcome by patient's own assessment: 1 -totally recovered; 2—slight sequelae; 3—obvious sequelae; 4—severe sequelae

${ }^{\mathrm{c}}$ Corticosteroid usually Prednisolon $60 \mathrm{mg} /$ day with tapering dosing $10 \mathrm{mg} / \mathrm{day}$ after 5 days for 10 days or Medrol $32 \mathrm{mg}$ or $64 \mathrm{mg} / \mathrm{day}$ for $7-10$ days

Patients are grouped by the medication type and medication start time at syndrome onset

Table 3 Outcome of facial palsy by patient's self-assessment questionnaire in comparison to initial facial palsy grade with patients (total number $=75$ ) receiving any amount of virus medication ( \pm corticosteroid) within $72 \mathrm{~h}$ from Ramsay Hunt syndrome onset

\begin{tabular}{|c|c|c|c|c|}
\hline $\begin{array}{l}\text { House-Brackman (HB) facial palsy grade at } \\
\text { Ramsay Hunt syndrome onset }\end{array}$ & $\begin{array}{l}\text { Totally cured (1): } \\
\text { patient number/\% }\end{array}$ & $\begin{array}{l}\text { Slight sequelae (2): patient } \\
\text { number/\%; } 1+2 \%\end{array}$ & $\begin{array}{l}\text { Obvious sequelae: } \\
\text { patient number/\% }\end{array}$ & $\begin{array}{l}\text { Severe sequelae: } \\
\text { patient number } / \%\end{array}$ \\
\hline HB II & $6 / 75 \%$ & $2 / 25 \% ; 100 \%$ & & \\
\hline HB III & $4 / 67 \%$ & $1 / 16 \% ; 83 \%$ & & $1 / 16 \%$ \\
\hline HB IV & $3 / 50 \%$ & $3 / 50 \% ; 100 \%$ & & \\
\hline HB V & $4 / 40 \%$ & $4 / 40 \% ; 80 \%$ & $2 / 20 \%$ & \\
\hline HB VI & $1 / 14 \%$ & $2 / 29 \% ; 43 \%$ & $4 / 57 \%$ & \\
\hline HB ? & $21 / 55 \%$ & $12 / 32 \% ; 87 \%$ & $3 / 8 \%$ & $2 / 5 \%$ \\
\hline Total patient number/\% per 75 patients & $39 / 52 \%$ & $24 / 32 \% ;(1+2) 84 \%$ & $9 / 12 \%$ & $3 / 4 \%$ \\
\hline
\end{tabular}

Table 4 Outcome of facial palsy by patient's self-assessment questionnaire in comparison to initial facial palsy grade with patients (total number 62 ) receiving maximal virus medication ( \pm corticosteroid) within $72 \mathrm{~h}$ from Ramsay Hunt syndrome onset

\begin{tabular}{|c|c|c|c|c|}
\hline $\begin{array}{l}\text { House-Brackman (HB) facial palsy grade at } \\
\text { Ramsay Hunt syndrome onset }\end{array}$ & $\begin{array}{l}\text { Totally cured (1): } \\
\text { patient number } / \%\end{array}$ & $\begin{array}{l}\text { Slight sequelae (2): patient } \\
\text { number } / \% ; 1+2 \%\end{array}$ & $\begin{array}{l}\text { Obvious sequelae: } \\
\text { patient number } \%\end{array}$ & $\begin{array}{l}\text { Severe sequelae: } \\
\text { patient number/\% }\end{array}$ \\
\hline HB II & $4 / 67 \%$ & $2 / 33 \% ; 100 \%$ & & \\
\hline HB III & $4 / 67 \%$ & $1 / 16 \% ; 83 \%$ & & $1 / 16 \%$ \\
\hline HB IV & $2 / 40 \%$ & $3 / 60 \% ; 100 \%$ & & \\
\hline HB V & $3 / 43 \%$ & $2 / 28 \% ; 71 \%$ & $2 / 28 \%$ & \\
\hline HB VI & $1 / 14 \%$ & $2 / 29 \% ; 43 \%$ & $4 / 57 \%$ & \\
\hline HB ? & $17 / 55 \%$ & $11 / 36 \% ; 91 \%$ & $2 / 6 \%$ & $1 / 3 \%$ \\
\hline Total patient number $/ \%$ per 62 patients & $31 / 50 \%$ & $21 / 34 \% ;(1+2) 84 \%$ & $8 / 13 \%$ & $2 / 3 \%$ \\
\hline
\end{tabular}

either full recovery or only mild sequelae was reported in $46 \%$ of cases, and in a study by DeVriese et al. [7] only $30 \%$ recovered to HB I \& II. Our results, even with antivirals as the only medication, were amongst the best recovery results published. The previous use of acyclovir could also worsen the outcome results compared to the later and present use of valasiclovir with easier dosing regimen. It remains to be seen whether the outcome results continue to improve with the wider usage of newer antivirals (e.g. famciclovir) as suggested in the study by Kim et al. [22].

When comparing the recovery results to the initial $\mathrm{HB}$ grade, the low patient numbers in each $\mathrm{HB}$ grade made statistically significant conclusions impossible, but there seemed to be a clear drop in the possibility of a favorable outcome if the paralysis was total at the onset. An outcome with only slight sequelae or better was only a little over 
Table 5 Outcome of facial palsy (known for 103 patients) by patient records and patient's self-assessment questionnaire in comparison to the initial facial palsy grade with patients (total number 107) receiv- ing any amount of virus medication ( \pm corticosteroid) within $72 \mathrm{~h}$ from Ramsay Hunt syndrome onset

\begin{tabular}{|c|c|c|c|c|c|}
\hline $\begin{array}{l}\text { House-Brackman (HB) facial palsy } \\
\text { grade at Ramsay Hunt syndrome } \\
\text { onset }\end{array}$ & $\begin{array}{l}\text { Totally cured (1); } \\
\text { patient number/\% }\end{array}$ & $\begin{array}{l}\text { Slight sequelae }(2) \text {; } \\
\text { patient number } \% \text {; } \\
1+2 \%\end{array}$ & $\begin{array}{l}\text { Obvious sequelae; } \\
\text { patient number/\% }\end{array}$ & $\begin{array}{l}\text { Severe sequelae; } \\
\text { patient num- } \\
\text { ber } \%\end{array}$ & $\begin{array}{l}\text { Outcome unknown; } \\
\text { patient number }\end{array}$ \\
\hline HB II & $8 / 80 \%$ & $2 / 20 \% ; 100 \%$ & & & \\
\hline HB III & $4 / 67 \%$ & $1 / 16 \% ; 83 \%$ & & $1 / 16 \%$ & 1 \\
\hline HB IV & $7 / 70 \%$ & $3 / 30 \% ; 100 \%$ & & & 1 \\
\hline HB V & $8 / 50 \%$ & $5 / 31 \% ; 81 \%$ & $3 / 19 \%$ & & \\
\hline HB VI & $2 / 20 \%$ & $2 / 20 \% ; 40 \%$ & $5 / 50 \%$ & $1 / 10 \%$ & 1 \\
\hline $\mathrm{HB}$ ? & $27 / 53 \%$ & $18 / 35 \% ; 88 \%$ & $4 / 8 \%$ & $2 / 4 \%$ & 1 \\
\hline $\begin{array}{l}\text { Total patient number } / \% \text { per } 103 \\
\text { patients }\end{array}$ & $56 / 54 \%$ & $31 / 30 \% ;(1+2) 84 \%$ & $12 / 12 \%$ & $4 / 4 \%$ & 4 (4\% of 107 patients) \\
\hline
\end{tabular}

Table 6 Outcome of facial palsy (known for 86 patients) by patient records and patient's self-assessment questionnaire in comparison to the initial facial palsy grade with patients (total number 90) receiving maximal amount of virus medication ( \pm corticosteroid) within $72 \mathrm{~h}$ from Ramsay Hunt syndrome onset

\begin{tabular}{|c|c|c|c|c|c|}
\hline $\begin{array}{l}\text { House-Brackman (HB) facial palsy } \\
\text { grade at Ramsay Hunt syndrome } \\
\text { onset }\end{array}$ & $\begin{array}{l}\text { Totally cured (1): } \\
\text { patient number/\% }\end{array}$ & $\begin{array}{l}\text { Slight sequelae }(2) \text { : } \\
\text { patient number/ } \% \\
1+2 \%\end{array}$ & $\begin{array}{l}\text { Obvious sequelae: } \\
\text { patient number/\% }\end{array}$ & $\begin{array}{l}\text { Severe sequelae: } \\
\text { patient num- } \\
\text { ber/\% }\end{array}$ & $\begin{array}{l}\text { Outcome not known: } \\
\text { patient number }\end{array}$ \\
\hline HB II & $6 / 75 \%$ & $2 / 25 \% ; 100 \%$ & & & \\
\hline HB III & $4 / 67 \%$ & $1 / 16 \% ; 83 \%$ & & $1 / 16 \%$ & 1 \\
\hline HB IV & $5 / 62 \%$ & $3 / 38 \% ; 100 \%$ & & & 1 \\
\hline HB V & $7 / 54 \%$ & $3 / 23 \% ; 77 \%$ & $3 / 23 \%$ & & \\
\hline HB VI & $2 / 20 \%$ & $2 / 20 \% ; 40 \%$ & $5 / 50 \%$ & $1 / 10 \%$ & 1 \\
\hline HB ? & $21 / 51 \%$ & $16 / 39 \% ; 90 \%$ & $3 / 7 \%$ & $1 / 3 \%$ & 1 \\
\hline $\begin{array}{l}\text { Total patient number } / \% \text { per } 86 \\
\text { patients }\end{array}$ & $45 / 52 \%$ & $27 / 31 \% ;(1+2) 83 \%$ & $11 / 13 \%$ & $3 / 4 \%$ & 4 (4\% of 90 patients) \\
\hline
\end{tabular}

Table 7 Outcome of facial palsy (known for 52 patients) by patient records and patient's self-assessment questionnaire in comparison to initial facial palsy grade with patients (total number 54) receiving any amount of virus medication with corticosteroids within $72 \mathrm{~h}$ from Ramsay Hunt syndrome onset

\begin{tabular}{|c|c|c|c|c|c|}
\hline $\begin{array}{l}\text { House-Brackman (HB) facial palsy } \\
\text { grade at Ramsay Hunt syndrome } \\
\text { onset }\end{array}$ & $\begin{array}{l}\text { Totally cured (1): } \\
\text { patient number/\% }\end{array}$ & $\begin{array}{l}\text { Slight sequelae }(2) \text { : } \\
\text { patient number } \% \text {; } \\
1+2 \%\end{array}$ & $\begin{array}{l}\text { Obvious sequelae: } \\
\text { patient number/\% }\end{array}$ & $\begin{array}{l}\text { Severe sequelae: } \\
\text { patient num- } \\
\text { ber } \%\end{array}$ & $\begin{array}{l}\text { Outcome not known; } \\
\text { patient number }\end{array}$ \\
\hline HB II & $3 / 60 \%$ & $2 / 40 \% ; 100 \%$ & & & \\
\hline HB III & $2 / 67 \%$ & $0 / 0 \% ; 67 \%$ & & $1 / 33 \%$ & \\
\hline HB IV & $5 / 71 \%$ & $2 / 29 \% ; 100 \%$ & & & 1 \\
\hline $\mathrm{HB} \mathrm{V}$ & $5 / 50 \%$ & $3 / 30 \% ; 80 \%$ & $2 / 20 \%$ & & \\
\hline HB VI & $3 / 38 \%$ & $0 / 0 \% ; 38 \%$ & $4 / 50 \%$ & $1 / 12 \%$ & 1 \\
\hline HB ? & $9 / 47 \%$ & $8 / 42 \% ; 89 \%$ & $2 / 11 \%$ & & \\
\hline $\begin{array}{l}\text { Total patient number/\% per } 52 \\
\text { patients }\end{array}$ & $27 / 52 \%$ & $15 / 29 \% ;(1+2) 81 \%$ & $8 / 15 \%$ & $2 / 4 \%$ & 2 (4\% of 54 patients) \\
\hline
\end{tabular}

$40 \%$, whereas already in HB V with any used virus medication it was $70-80 \%$. Still, the outcome seemed better than for those receiving no medication or starting it later than $72 \mathrm{~h}$ although the patient number in both these groups was so small that the results were easily affected by any single patient's outcome.

The mantra we all have probably repeated, that patients with RHS recover worse than those with Bell's palsy, is still 
Table 8 Outcome of facial palsy (known for 51 patients) by patient records and patient's self-assessment questionnaire in comparison to initial facial palsy grade with patients (total number 53) receiving any amount of virus medication without corticosteroids within $72 \mathrm{~h}$ from Ramsay Hunt syndrome onset

\begin{tabular}{|c|c|c|c|c|c|}
\hline $\begin{array}{l}\text { House-Brackman (HB) facial palsy } \\
\text { grade at Ramsay Hunt syndrome } \\
\text { onset }\end{array}$ & $\begin{array}{l}\text { Totally cured (1): } \\
\text { patient number/\% }\end{array}$ & $\begin{array}{l}\text { Slight sequelae }(2) \text { : } \\
\text { patient number } \% \text {; } \\
1+2 \%\end{array}$ & $\begin{array}{l}\text { Obvious sequelae: } \\
\text { patient number } / \%\end{array}$ & $\begin{array}{l}\text { Severe sequelae: } \\
\text { patient num- } \\
\text { ber } / \%\end{array}$ & $\begin{array}{l}\text { Outcome not known; } \\
\text { patient number }\end{array}$ \\
\hline HB II & $5 / 100 \%$ & & & & \\
\hline HB III & $2 / 67 \%$ & $1 / 33 \% ; 100 \%$ & & & 1 \\
\hline HB IV & $2 / 76 \%$ & $1 / 33 \% ; 100 \%$ & & & \\
\hline $\mathrm{HB} \mathrm{V}$ & $3 / 50 \%$ & $2 / 33 \% ; 83 \%$ & $1 / 17 \%$ & & \\
\hline HB VI & & $2 / 67 \% ; 67 \%$ & $1 / 33 \%$ & & \\
\hline HB ? & $17 / 55 \%$ & $10 / 32 \% ; 87 \%$ & $2 / 6 \%$ & $2 / 6 \%$ & 1 \\
\hline $\begin{array}{l}\text { Total cure patient number/\% per } 51 \\
\text { patients }\end{array}$ & $29 / 57 \%$ & $16 / 31 \% ; 1+2 / 88 \%$ & $4 / 8 \%$ & $2 / 4 \%$ & 2 (4\% of 53 patients) \\
\hline
\end{tabular}

likely to be true, but the gap might not be as wide as we have thought. If we assess Bell's palsy patients meticulously, the end result, even with corticosteroid treatment, is that about $30 \%$ of the patients are left with some degree of sequelae, although mostly slight [23]; not very different from the results achieved in this study.

\section{Hearing loss}

About half of our study patients experienced hearing loss at some point of the illness, with only $20 \%$ reporting constant hearing loss after the illness. Since this result was based on patients' own reports, other reasons for hearing loss (e.g. prespyacusis) could also influence the outcome. In the study by Coulson et al. [21], $42 \%$ of the patients reported hearing loss and $50 \%$ had hearing deterioration on the affected site on audiometric measurement (any asymmetry to the unaffected side). Shin et al. [24] reported hearing loss in $74 \%$ of the patients studied ( $\geq 10 \mathrm{~dB}$ difference to the unaffected side). Neither of these retrospective studies commented on the end result of the hearing loss. In Peitersen's prospective FP study [6], 73\% of the RHS patients had hearing loss. He states as a rule that the hearing loss is non-reversible. This was not true in our study, even amongst those patients that underwent end-outcome audiometry tests-many recovered. The same view was presented by Wayman et al. [25], with only $5 \%$ of the patients with residual hearing loss after RHS.

\section{Blisters}

In our study, herpes blisters were most often found in the ear, followed by the mouth cavity, but also to a minor extent without ear or mouth involvement in other parts of the head and neck. In Peitersen's study [6], the ear was affected in $66 \%$ of cases, face in $15 \%$, and mouth cavity in $9 \%$. In a study by Coulson et al. [21], inclusion criteria for the study consisted of blisters only in the ear or mouth, with the ear affected in $85 \%$ of the cases, mouth in $7 \%$, and both in $8 \%$ of the cases.

With our patients, the herpes blisters preceded the FP in $48 \%$ of the cases, were simultaneous in $16 \%$, and followed the FP in $36 \%$ of the cases. In Peitersen's study [6], blisters occurred first in $60 \%$ of the cases, were simultaneous in $25 \%$, and followed FP in $15 \%$ of the cases. Aizawa et al. [3] found that blisters preceded the palsy $31 \%$, occurred at the same time as the palsy $52 \%$, and followed the palsy $15 \%$. Hato et al. [26] found a difference between children and adults in the way that blisters followed FP in $32 \%$ of adults, but even in $50 \%$ of children 16 years or younger. In our study, over one third of the RHS diagnoses could not be made at FP onset because the blisters were yet to come. It is a serious reminder to advise the patients to be alert of blisters appearing after FP. It is very probable that some of these patients are lost for diagnosis and treatment in cases of blisters following FP.

In our study design, we set the time boundaries for the herpes blisters to be 1 month before or after the FP and some patients showed the blisters 14-30 days before or after FP. In the study by Aizawa et al. [3], the blisters were seen from 27 days before to 13 days after the FP. They studied the viral load and immune responses of the patients and concluded that FP in RHS can occur at different times, from early phase to the regression phase of VZV reactivation, and that there are variable patterns of development of facial nerve dysfunction induced by VZV reactivation and the progression of neuritis.

\section{Strengths and limitations}

The strength of this study was the rare long-term outcome assessment of FP by self-assessment of a rather large group of patients. The exploration of many different characteristics of RHS was also valuable, revealing, among other things, 
the knowledge that with over one third of the patients, the blisters appeared after FP onset and in $20 \%$ of the patients the blisters were hidden in the ear canal or in the mouth, and could not be seen if not looked for.

A limitation of the study was that the protocol failed to permit standardized gradings of FP from the patient records at the baseline visit or at the end of the follow-up period. Facial function evaluations varied from brief mentions of "almost total paralysis", "slight weakness", "almost cured", or "well cured" to the use of both HB and SB grading scales. The study data was collected already several years ago and goes back over 20 years. We hope that our routines on evaluating FP patients are more coordinated today than what they were in the 1990s, and that the SB grading scale is frequently used also by residents who usually first meet these patients in the outpatient clinics. In addition, the time the patient was first seen and evaluated after FP onset and the length of the follow-up varied between patients. The time gap from RHS onset to answering the questionnaire was also long in some cases, which likely affected how the patient was able to remember and answer about the symptoms at the disease onset. Finally, the number of patients in subgroups was also too small to draw statistically liable conclusions.

\section{Conclusions}

Medication seems to significantly advance the outcome of RHS, thus it is important to recognize the disease. In our study, only $16 \%$ of patients displayed blisters occuring simultaneously with FP, so it is crucial to ask the patients about preceding blisters and inform them about the possibility of blisters occurring after FP. In addition, $18 \%$ of our patients experienced their blisters at the ear canal or in the mouth, hidden from view, therefore it is imperative to meticulously check the patient throughout.

Acknowledgements Open access funding provided by University of Helsinki including Helsinki University Central Hospital.

Funding This work was supported by Helsinki University Hospital Research Funds. The funding source was not involved in the study design; in the collection, analysis, and interpretation of data; in the writing of the report; and in the decision to submit this manuscript for publication.

\section{Compliance with ethical standards}

Conflict of interest The authors declare that they have no conflict of interest.

Ethical standards The Ethics Committee of the Helsinki University Hospital approved the study and institutional research approval was granted.
Informed consent All patients taking part in the questionnaire study gave their written informed consent.

Open Access This article is licensed under a Creative Commons Attribution 4.0 International License, which permits use, sharing, adaptation, distribution and reproduction in any medium or format, as long as you give appropriate credit to the original author(s) and the source, provide a link to the Creative Commons licence, and indicate if changes were made. The images or other third party material in this article are included in the article's Creative Commons licence, unless indicated otherwise in a credit line to the material. If material is not included in the article's Creative Commons licence and your intended use is not permitted by statutory regulation or exceeds the permitted use, you will need to obtain permission directly from the copyright holder. To view a copy of this licence, visit http://creativecommons.org/licenses/by/4.0/.

\section{References}

1. Shim HJ, Jung H, Park DC, Lee JH, Yeo SG (2011) Ramsay Hunt syndrome with multicranial nerve involvement. Acta Otolaryngol 131(2):210-215

2. Sweeney CJ, Gilden DH (2001) Ramsay Hunt syndrome. J Neurol Neurosurg Psychiatry 71:149-154

3. Aizawa H, Ohtani F, Furuta Y, Sawa H, Fukuda S (2004) Variable patterns of varicella-zoster virus reactivation in Ramsay Hunt syndrome. Med Virol 74(2):355-360

4. Alicandri-Ciufelli M, Aggazzotti-Cavazza E, Genovese E, Monzani D, Presutti L (2012) Herpes zoster oticus: a clinical model for a transynaptic, reflex pathways, viral transmission hypotheses. Neurosci Res 74(1):7-9

5. Kim YH, Chang MY, Jung HH et al (2010) Prognosis of Ramsay Hunt syndrome presenting as cranial polyneuropathy. Laryngoscope 120(11):2270-2276

6. Peitersen E (2002) Bell's palsy: the spontaneous course of 2500 peripheral facial nerve palsies of different etiologies. Acta Otolaryngol Suppl 549:4-30

7. Devriese PP, Moesker WH (1988) The natural history of facial paralysis in herpes zoster. Clin Otolaryngol Allied Sci 13:289-298

8. Robillard RB, Hilsinger RL Jr, Adour KK (1986) Ramsay Hunt facial paralysis: clinical analyses of 185 patients. Otolaryngol Head Neck Surg 95:292-297

9. Uscategui T, Doree C, Chamberlain IJ, Burton MJ (2008) Antiviral therapy for Ramsay Hunt syndrome (herpes zoster oticus with facial palsy) in adults. Cochrane Database Syst Rev 4:006851

10. Uscategui T, Doree C, Chamberlain IJ, Burton MJ (2008) Corticosteroids as adjuvant to antiviral treatment in Ramsay Hunt syndrome (herpes zoster oticus with facial palsy) in adults. Cochrane Database Syst Rev 3:006852

11. de Ru JA, van Benthem PP (2011) Combination therapy is preferable for patients with Ramsay Hunt syndrome. Otol Neurotol 32(5):852-855

12. Whitley RJ (2009) A 70-year-old woman with shingles: review of herpes zoster. JAMA 302(1):73-80

13. Bean B, Braun C, Balfour HH Jr (1982) Acyclovir therapy for acute herpes zoster. Lancet 2(8290):118-121

14. Murakami S, Hato N, Horiuchi J, Honda N, Gyo K, Yanagihara N (1997) Treatment of Ramsay Hunt syndrome with acyclovirprednisone: Significance of early diagnosis and treatment. Ann Neurol 41:353-357

15. House JW, Brackmann DE (1985) Facial nerve grading system. Otolaryngol Head Neck Surg 93(2):146-147 
16. Neely JG, Cherian NG, Dickerson CB, Nedzelski JM (2010) Sunnybrook facial grading system: reliability and criteria for grading. Laryngoscope 120(5):1038-1045

17. Kanerva M, Jonsson L, Berg T et al (2011) Sunnybrook and House-Brackmann systems in 5397 facial gradings. Otolaryngol Head Neck Surg 144(4):570-574

18. Uri N, Greenberg E, Kitzes-Cohen R, Doweck I (2003) Acyclovir in the treatment of Ramsay Hunt syndrome. Otolaryngol Head Neck Surg 129(4):379-381

19. Kinishi M, Amatsu M, Mohri M (2001) Acyclovir improves recovery rate of facial nerve palsy in Ramsay Hunt syndrome. Auris Nasus Larynx 28:223-226

20. Zainine R, Sellami M, Charfeddine A, Beltaief N, Sahtout S, Besbes G (2012) Ramsay Hunt syndrome. Eur Ann Otorhinolaryngol Head Neck Dis 129(1):22-25

21. Coulson S, Croxson GR, Adams R, Oey V (2011) Prognostic factors in herpes zoster oticus (Ramsay Hunt syndrome). Otol Neurotol 32(6): 1025-1030

22. Kim HJ, Jung J, Kim SS, Byun JY, Park MS, Yeo SG (2017) Comparison of acyclovir and famciclovir for Ramsay Hunt syndrome. Otol Neurotol 38(5):754-758
23. Engström M, Berg T, Stjernquist-Desatnik A et al (2008) Prednisolone and valaciclovir in Bell's palsy: a randomised, double-blind, placebo-controlled, multicentre trial. Lancet Neurol 7:993-1000

24. Shin DH, Kim BR, Shin JE, Kim CH (2016) Clinical manifestations in patients with herpes zoster oticus. Eur Arch Otorhinolaryngol 273(7):1739-1743

25. Wayman DM, Pham HN, Byl FM, Adour KK (1990) Audiological manifestations of Ramsay Hunt syndrome. J Laryngol Otol 104(2):104-108

26. Hato N, Kisaki H, Honda N, Gyo K, Murakami S, Yanagihara N (2000) Ramsay Hunt syndrome in children. Ann Neurol $48: 254-256$

Publisher's Note Springer Nature remains neutral with regard to jurisdictional claims in published maps and institutional affiliations. 